\title{
Per Centimeter of Water
}

National Cancer Institute

\section{Source}

National Cancer Institute. Per Centimeter of Water. NCI Thesaurus. Code C135517.

A unit of pressure equal to one centimeter of water used as a denominator to build a derived unit expressed as a ratio. 